\title{
Health-based audible noise guidelines account for infrasound and low-frequency noise produced by wind turbines
}

\author{
Robert G. Berger ${ }^{1}$, Payam Ashtiani ${ }^{2}$, Christopher A. Ollson ${ }^{3}$, Melissa Whitfield Aslund ${ }^{3}$, \\ Lindsay C. McCallum ${ }^{3,4}$, Geoff Leventhall ${ }^{5}$ and Loren D. Knopper ${ }^{3 *}$ \\ 1 Intrinsik Health Sciences Inc., Mississauga, ON, Canada \\ ${ }^{2}$ Aercoustics Engineering Limited, Mississauga, ON, Canada \\ ${ }^{3}$ Intrinsik Environmental Sciences Inc., Mississauga, ON, Canada \\ ${ }^{4}$ Department of Physical and Environmental Sciences, University of Toronto, Toronto, ON, Canada \\ ${ }^{5}$ H.G. Leventhall - Consultancy, Surrey, UK
}

\section{Edited by:}

Keith L. Keene, East Carolina

University, USA

Reviewed by:

Timothy Joe Wade, United States Environmental Protection Agency, USA

Brian Howe, Howe Gastmeier

Chapnik Limited, Canada

*Correspondence:

Loren D. Knopper, Intrinsik

Environmental Sciences Inc., 6605

Hurontario Street, Suite 500

Mississauga, ON L5T OA3, Canada

e-mail: Iknopper@intrinsik.com
Setbacks for wind turbines have been established in many jurisdictions to address potential health concerns associated with audible noise. However, in recent years, it has been suggested that infrasound (IS) and low-frequency noise (LFN) could be responsible for the onset of adverse health effects self-reported by some individuals living in proximity to wind turbines, even when audible noise limits are met. The purpose of this paper was to investigate whether current audible noise-based guidelines for wind turbines account for the protection of human health, given the levels of IS and LFN typically produced by wind turbines. New field measurements of indoor IS and outdoor LFN at locations between 400 and $900 \mathrm{~m}$ from the nearest turbine, which were previously underrepresented in the scientific literature, are reported and put into context with existing published works. Our analysis showed that indoor IS levels were below auditory threshold levels while LFN levels at distances $>500 \mathrm{~m}$ were similar to background LFN levels. A clear contribution to LFN due to wind turbine operation (i.e., measured with turbines on in comparison to with turbines off) was noted at a distance of $480 \mathrm{~m}$. However, this corresponded to an increase in overall audible sound measures as reported in $\mathrm{dB}(\mathrm{A})$, supporting the hypothesis that controlling audible sound produced by normally operating wind turbines will also control for LFN. Overall, the available data from this and other studies suggest that health-based audible noise wind turbine siting guidelines provide an effective means to evaluate, monitor, and protect potential receptors from audible noise as well as IS and LFN.

Keywords: wind turbines, infrasound, low-frequency noise, health, human perception, noise, sound pressure level, annoyance

\section{INTRODUCTION}

Wind-based energy production has been identified as a clean and renewable resource that does not produce any known emissions or harmful wastes (1). As a result, wind power has become the fastest growing source of new electric power generation, with several countries achieving high levels of wind power capacity and overall penetration (2). Within the last decade, wind power generation has increased substantially in Canada. In the province of Ontario alone, $1,700 \mathrm{MW}$ ( $5 \%$ of Ontario's energy generation) have been installed since 2006, with an additional 2,000 MW expected to be installed by the end of 2014 (3). Public support for the use of wind energy is typically high; however, acceptance of projects at the local level does not always reflect this trend. While support is found in some locations, strong opposition stemming from concerns of visual esthetics, health risk perception, and noise levels can be found in others (4-7).

Currently, there exists an ongoing debate surrounding the relationship between wind turbines and human health within both the public and the scientific communities (8). This debate is driven by the fact that some people that live near wind turbines have reported adverse health effects such as (but not limited to) ringing in ears, headaches, lack of concentration, vertigo, and sleep disruption that they attribute to the wind turbines. Some argue that reported health effects are related to wind turbine operational effects [e.g., electromagnetic fields (EMF), shadow flicker from rotor blades, audible noise, low-frequency noise (LFN), and infrasound (IS)]; others suggest that when turbines are sited correctly, reported effects are more likely attributable to a number of subjective variables, including nocebo responses, where the etiology of the self-reported effect is in beliefs and expectations rather than a physiologically harmful entity (9-13). Indeed, there are numerous peer-reviewed studies on the issue and governmental reviews of these studies (14-16).

It is well known that exposure to excessive levels of audible noise, regardless of the source, can cause annoyance, sleep disturbance, cognitive impairment, and other serious health effects. According to the World Health Organization (WHO), nighttime exposure to noise levels above $55 \mathrm{~dB}(\mathrm{~A})$ outdoors averaged 
over the year is considered increasingly dangerous for public health and a sizeable proportion of the population will be highly annoyed and sleep-disturbed (17). As a result, jurisdictions across the globe have developed noise regulations specific to wind turbine projects to protect the public from potential noise-related health effects (Table 1). Guidelines are found at various levels of governmental structure including country, state/province, and county/municipality. The list in Table $\mathbf{1}$ is not globally comprehensive yet is wide-ranging and inclusive of numerous jurisdictions. Though some variability exists among jurisdictions, the majority of the guidelines center around an outdoor limit between 35 and $45 \mathrm{~dB}(\mathrm{~A})$. This limit coincides with the WHO Europe nighttime noise guideline of $40 \mathrm{~dB}(\mathrm{~A})$ outdoors, a health-based value derived to "protect the public, including the most vulnerable groups such as children, the chronically ill and the elderly, from the adverse health effects of night noise" (17).

Even when these health-based noise limits are met, some people living near wind turbines self-report a variety of adverse health effects that they attribute to living near the wind turbines $(8,16)$. As a result, the etiology of these health effects has been hypothesized by some to stem from exposure to low-frequency sounds, including IS $(0.01-20 \mathrm{~Hz})$ and LFN $(10-200 \mathrm{~Hz})(36-38)$, both of which are known components of the broad-band sound associated with normal wind turbine operation $(9,39,40)$. For example, in 2011 Møller and Pedersen (38) stated "Even when A-weighted levels are considered, a substantial part of the noise is at low frequencies, and for several of the investigated large turbines, the one-third-octave band with the highest level is at or below $250 \mathrm{~Hz}$. It is thus beyond any doubt that the low-frequency part of the spectrum plays an important role in the noise ...." In response to these concerns, a number of investigations (published since 2010) have measured IS and LFN associated with modern wind turbine operation at a variety of distances, operating scenarios, and geographic and meteorological conditions (Tables 2 and $\mathbf{3}$ ). Collectively, these reports suggest that sound associated with well-functioning wind turbines has measurable energy within the IS and LFN spectra. However, IS levels, which are often described in $\mathrm{dB}(\mathrm{G})$, are consistently well below auditory perceptual levels (41-45) and LFN is below available guidelines (42). Furthermore, IS levels at relatively close distances to wind turbines are equivalent to or less than those produced by a number of natural or engineered sources that individuals are exposed to on a regular basis $(43,44,46)$. The physical characteristics of sounds emitted from wind turbines have been recognized to influence the perception and annoyance to wind turbine associated sounds; however, this generally refers to sounds that are above the auditory level of perception $(10,47,48)$.

It has been suggested that wind turbine noise limits set in $\mathrm{dB}(\mathrm{A})$, which simulates the sensitivity of human hearing and perception, may underestimate the contribution of IS and LFN from wind turbines (37). Alternative sound weightings, including G-weighting $[\mathrm{dB}(\mathrm{G})]$ and $\mathrm{C}$-weighting $[\mathrm{dB}(\mathrm{C})]$, have been proposed as more appropriate metrics for noise limits when LFN and IS are present, respectively $(37,49)$. However, Health Canada recently suggested that, in the case of wind turbine noise, there was "no additional benefit in assessing LFN as C-and A-weighted levels were so highly correlated ( $r=0.94)$ that they essentially provided the same information" (50). Accordingly, the purpose of this paper is to examine further
IS, LFN, and overall sound levels typically produced by wind turbines and provide discussion as to whether concerns regarding wind turbine associated IS and LFN are warranted. Field measurements of outdoor LFN and overall sound levels and indoor IS at locations between 400 and $900 \mathrm{~m}$ from the nearest wind turbine, which were previously underrepresented in the scientific literature, are reported. The results of these measurements are put into context with existing published works and current available guidelines based on $\mathrm{dB}(\mathrm{A})$ to provide a weight-of-evidence conclusion.

\section{MATERIALS AND METHODS \\ INDOOR INFRASOUND MEASUREMENTS}

Sound measurements were conducted in three residences, two at $450 \mathrm{~m}$ and one at $900 \mathrm{~m}$ from the nearest wind turbine. These turbines were part of an operating wind farm with over 40 turbines, each with a power capacity of $1.5 \mathrm{MW}$. The measurements were carried out using Class 1 instrumentation with sufficiently low-frequency range and noise floor. Measurements were carried out on a ground plane fitted with a double windscreen. The double wind screen consisted of the thin hemispherical wireframe ( $450 \mathrm{~mm}$ diameter) covered with a thin layer (approximately $10 \mathrm{~mm}$ ) of open cell foam. This setup is consistent with that defined in IEC 61400-11 with the exception that the measurement location was at a dwelling rather than close to a wind turbine. Although not in a windy environment, a double windscreen helps protect very low frequency and infrasonic measured levels against pressure fluctuations within a dwelling caused by moving air from ventilation and opening/closing doors.

For these measurements, access was not available to turbines in order to conduct on/off tests for quantifying ambient levels. Additionally, turbine power performance was not made available during the study. In order to identify whether the turbines in the facility were operating, an autocorrelation technique was used in the signal analysis in order to detect characteristics in the sound signal attributable to the turbine operation. This autocorrelation technique (52) exploits the periodicity in the signal attributable to the wind turbine operation and uses this feature to detect when the turbines were operating. IS levels measured during wind turbine operation were compared to those when the wind turbines were unlikely to be operational (i.e., at wind speeds below turbine cut-in at $3 \mathrm{~m} / \mathrm{s}$ ). Data were collected from 1 to $1000 \mathrm{~Hz}$ and subsequently weighted using $\mathrm{dB}(\mathrm{G})$ to focus the analysis on the IS component, and allow for comparison to other studies.

The data presented in this report represent the periods where 1min interval recordings showed the existence of the wind turbine noise (i.e., characteristic blade passage frequencies) the clearest out of the entire measurement period, which was 3-4 weeks. Because the nature of the signal detection mechanism, and the averaging over a minute, the Type A uncertainty for the measured value is difficult to quantify. The Type B uncertainty of the measurement is that of a Class 1 instrumentation, which is typically $\pm 1 \mathrm{~dB}$.

\section{OUTDOOR LOW-FREQUENCY NOISE AND OVERALL SOUND MEASUREMENTS}

Sound levels were measured near two different wind turbine facilities, both with more than 30 wind turbines each. The turbines had a power capacity between 1.5 and 2.4 MW. Measurements were 
Table 1 | Current or proposed wind turbine noise limits per jurisdiction

Country/region

Noise limits

Reference

Australia/New

South Wales

"For a new wind farm development, the predicted equivalent noise level ( $\mathrm{L}$ eq, 10 min), adjusted for any excessive levels of tonality, amplitude modulation, or low frequency, but including all other normal wind farm characteristics should not exceed $35 \mathrm{~dB}(\mathrm{~A})$ or the background noise ( $\mathrm{L} 90)$ by more than $5 \mathrm{~dB}(\mathrm{~A})$, whichever is the greater, at all relevant receivers not associated with the wind farm, for wind speed from cut-in to rated power of the WTG and each integer wind speed in between. The noise criteria must be established on the basis of separate daytime (7 a.m. to 10 p.m.) and night-time (10 p.m. to 7 a.m.) periods" ... "criteria have been set to restrict noise generated by wind turbines to $5 \mathrm{~dB}(\mathrm{~A})$ below the lowest acceptable noise criteria for a suburban or rural amenity area [which is $40 \mathrm{~dB}(\mathrm{~A})$ at night]"

Australia/South Background noise is to be measured at the wind farm at various wind speeds at which the turbines operate to determine masking effects of wind generated noise at relevant receiver locations. Noise level predictions are to be identified at all relevant receiver locations. Wind farm noise levels, which may be adjusted for tonality, should not exceed " $35 \mathrm{~dB}(\mathrm{~A})$ at relevant receivers in localities, which are primarily intended for rural living, or $40 \mathrm{~dB}(\mathrm{~A})$ at relevant receivers in localities in other zones, or the background noise $(L A e q, 10)$ by more than $5 \mathrm{~dB}(A)$, whichever is greater." Wind turbine setback distances are then based on these criteria

Australia/Western Sound generated from wind farms should not exceed $5 \mathrm{~dB}(\mathrm{~A})$ above the background sound level or $35 \mathrm{~dB}(\mathrm{~A})$ using a 10-min L Aeq, whichever is greater. Measurements are to be taken at noise-sensitive premises. Setback limits are based on data obtained from sound studies with a $1 \mathrm{~km}$ guideline

Australia/Nictoria Noise level limits are set in accordance with the New Zealand Standard NZS 6808:2010 where "the level of sound from a wind farm should not exceed the background sound level by more than $5 \mathrm{~dB}$, or a level of $40 \mathrm{~dB} L \mathrm{~A} 90$ (10 min), whichever is the greater"... "despite any other condition of this permit, no plans will be endorsed by the responsible authority, and no variation to the endorsed plans will be approved by the responsible authority, which allow a turbine to be located with $2 \mathrm{~km}$ of an existing dwelling ... unless evidence has been provided to the satisfaction of the responsible authority that the owner of the dwelling has consented in writing to the location of the turbine"

Canada/Alberta The minimum basic sound level used to calculate the permissible sound level is $40 \mathrm{~dB}(\mathrm{~A}) \mathrm{L}$ eq nighttime with adjustments made for proximity to transportation and population density. The night noise limits should remain between 40 and $56 \mathrm{~dB}(\mathrm{~A}) \mathrm{LA}$ eq, based on the number of other residences and existing infrastructure noise sources. For most wind energy locations, the night noise limits will probably fall between 40 and $46 \mathrm{~dB}(\mathrm{~A}) \mathrm{LA}$ eq. The day noise limits are $10 \mathrm{~dB}(\mathrm{~A})$ above night limits

Canada/British Outdoor sound levels measured at an existing residence are to not exceed a maximum of $40 \mathrm{~dB}(\mathrm{~A})$ based on wind

Columbia speed 8-11 m/s. More specifically, "where ambient conditions are $35 \mathrm{~dB}(\mathrm{~A})$ or less: night-time criterion: $\mathrm{L}$ eq, $9 \mathrm{~h}$ of $40 \mathrm{~dB}(\mathrm{~A})$ between 10:00 p.m. and 7:00 a.m.; Day-time criterion: $L$ eq, $15 \mathrm{~h}$ of $40 \mathrm{~dB}(\mathrm{~A})$ between 7:00 a.m. and 10:00 p.m.; Ambient conditions are to be assumed at $35 \mathrm{~dB}(\mathrm{~A})$ for calculation purposes. Where ambient conditions are shown to be $>35 \mathrm{~dB}(\mathrm{~A})$ during either the day or night (except where another wind power project is present), $a$ $5 \mathrm{~dB}(\mathrm{~A})$ increment may be applied to a measured background sound level to determine the day or night criterion, to a maximum of $50 \mathrm{~dB}(\mathrm{~A}) "$

Canada/Manitoba Sound limits are based on the levels recommended by CanWEA where a sliding scale based on wind speed is used. These levels start at $40 \mathrm{~dB}(\mathrm{~A})$ at a wind speed of $4 \mathrm{~m} / \mathrm{s}$ and rise to $53 \mathrm{~dB}(\mathrm{~A})$ at $11 \mathrm{~m} / \mathrm{s}$. For setback limits, sound modeling-based assessments have been used to determine that 500-550 $\mathrm{m}$ from a receptor (an occupied dwelling) is sufficient to ensure that the sound criteria can be met

Canada/New At a wind speed of $7 \mathrm{~m} / \mathrm{s}$ the overall noise limit is $40 \mathrm{~dB}(\mathrm{~A})$, this value increases with increasing wind speeds to Brunswick $53 \mathrm{~dB}(\mathrm{~A})$ at speeds $\geq 10 \mathrm{~m} / \mathrm{s}$. Proposed wind farms must demonstrate compliancy with these guidelines for all sensitive receptors, including homes and recreational areas within $1 \mathrm{~km}$ of the turbine. These values are used to determined setback distances

Canada/Ontario "If the wind turbine(s) are audible in a recording (does not include extraneous noise sources) then additional analysis is required for the subject recording: determine the value of the $10 \mathrm{~min} L$ eq via software or obtain it directly from the recording device; determine if the wind turbine noise is tonal; obtain the average wind speed at the microphone height $(1.5$ or $4.5 \mathrm{~m}$ ) over the 10 min recording session." "Results of the $10 \mathrm{~min} L$ eq (including tonal penalty if applicable) are to be compared against the applicable sound level limits contained in the 2008 Noise Guidelines" where at standardized wind speeds at $10 \mathrm{~m}$ height from below 5-10 m/s the sound level limit ranges from 40 to $51 \mathrm{~dB}(\mathrm{~A})$ 


\section{Table 1 | Continued}

\section{Country/region}

Canada/Quebec Based on a review by the Minnesota Department of Commerce, municipalities determine setbacks in the Province of

Quebec, with $500 \mathrm{~m}$ being the most commonly used setback distance. No noise guidelines were reported. However, it does appear the Province of Quebec has a nighttime rural noise limit (zone 1) of $40 \mathrm{~dB}(\mathrm{~A})$ that is not wind turbine specific

Denmark "The total noise impact from wind turbines may not exceed the following limit values: (1) at the most noise-exposed point in outdoor living area no more than $15 \mathrm{~m}$ from dwellings in open countryside: (a) $44 \mathrm{~dB}(\mathrm{~A})$ at a wind speed of $8 \mathrm{~m} / \mathrm{s}$. (b) $42 \mathrm{~dB}(\mathrm{~A})$ at a wind speed of $6 \mathrm{~m} / \mathrm{s}$. (2) At the most noise-exposed point in areas with noise-sensitive land use: (a) $39 \mathrm{~dB}(\mathrm{~A})$ at a wind speed of $8 \mathrm{~m} / \mathrm{s}$. (b) $37 \mathrm{~dB}(\mathrm{~A})$ at a wind speed of $6 \mathrm{~m} / \mathrm{s}^{\prime \prime}$

Germany "For immission points outside buildings, the binding immission values for the rating level are (a) in industrial areas $70 \mathrm{~dB}(\mathrm{~A})$; (b) in commercial zones during the day $65 \mathrm{~dB}(\mathrm{~A})$ at night $50 \mathrm{~dB}(\mathrm{~A})$; (c) in core areas, village areas, and mixed-use zones during the day $60 \mathrm{~dB}(\mathrm{~A})$ at night $45 \mathrm{~dB}(\mathrm{~A})$; (d) in general residential areas and small residential estate areas during the day $55 \mathrm{~dB}(\mathrm{~A})$ at night $40 \mathrm{~dB}(\mathrm{~A})$; (e) in purely residential areas during the day $50 \mathrm{~dB}(\mathrm{~A})$ at night $35 \mathrm{~dB}(\mathrm{~A})$; ( $f$ ) in spa areas, for hospitals and nursing homes during the day $45 \mathrm{~dB}(\mathrm{~A})$ at night $35 \mathrm{~dB}(\mathrm{~A})$ "

Ireland

A minimum setback distance of $500 \mathrm{~m}$ has been suggested, but is not absolute "because of the lack of correlation between separation distance and wind turbine sound levels, the use of a defined setback of turbines ... is not appropriate" .... An outdoor limit of $40 \mathrm{~dB}(\mathrm{~A})$ "attributed to one or more wind turbines, should be applied in order to restrict noise from wind turbines at noise sensitive properties" was defined. Post construction noise levels can be measured at wind farms to confirm if noise regulations are being met

New Zealand "The level of sound from a wind farm should not exceed the background sound level by more than $5 \mathrm{~dB}$, or a level of $40 \mathrm{~dB} L \mathrm{~A} 90$ (10 min), whichever is the greater. About $40 \mathrm{~dB}$ is typical of a quiet residential area with only light traffic and natural sounds such as the wind in the trees. In contrast, sound levels along-side an urban road would be around 60-70 dB during the day and about 50-60 dB at night. There are some locations that are particularly quiet at times and so the recommended limit of $40 \mathrm{~dB}$ would be considered to be unreasonable".... "Where a local authority has identified in its district plan the need to provide a higher degree of protection of acoustic amenity. The standard recommends that when particular conditions are met, the sound from the wind farm during the evening and night time should not exceed the background sound level by more than $5 \mathrm{~dB}$ or a level of $35 \mathrm{~dB}$ LA90(10 min), whichever is the greater"

UK/England For both day and night time, noise is recommended to be limited to $5 \mathrm{~dB}(\mathrm{~A})$ above background noise. There is a fixed night limit of $43 \mathrm{~dB}(\mathrm{~A})$ using $L \mathrm{~A} 90$ (10 min) or $45 \mathrm{~dB}(\mathrm{~A})$ for properties benefiting financially from wind turbine development. A penalty of up to $5 \mathrm{~dB}(\mathrm{~A})$ may be added if a distinct tone is distinguishable. England has no minimum setback distance though the noise limits suggest a minimum of $350 \mathrm{~m}$ for a typical wind turbine

USA/Oregon For noise generated by a wind energy facility, the assumed background L50 noise levels if $26 \mathrm{~dB}(\mathrm{~A})$ or the actual ambient background level. "The noise levels from a wind energy facility may increase the ambient statistical noise levels L10 and L50 by more than $10 \mathrm{~dB}(\mathrm{~A}) "$.... Noise levels at the appropriate measurement point are predicted assuming that all of the proposed wind facility's turbines are operating between cut-in speed and the wind speed corresponding to the maximum sound power level established by IEC 61400-11 (version 2002-12)

USA/

Massachusetts

USA/New Hampshire USA/Maine
Massachusetts has draft "Promising Practices for Nighttime Sound Pressure Levels by Land Use Type" for wind turbine noise. These values were provided in a 2012 report (Wind Turbine Health Impact Study). MassDEP convened a technical advisory group to consider potential revisions to its noise regulations and policy. The promising practices for nighttime sound pressure levels are industrial areas $70 \mathrm{~dB}(\mathrm{~A})$; Commercial areas $50 \mathrm{~dB}(\mathrm{~A})$; villages, mixed usage $45 \mathrm{~dB}(\mathrm{~A})$; sparsely populated areas, $8 \mathrm{~m} / \mathrm{s}$ wind $44 \mathrm{~dB}(\mathrm{~A})$; sparsely populated areas, $6 \mathrm{~m} / \mathrm{s}$ wind $42 \mathrm{~dB}(\mathrm{~A})$; residential areas, $8 \mathrm{~m} / \mathrm{s}$ wind $39 \mathrm{~dB}(\mathrm{~A})$; residential areas, $6 \mathrm{~m} / \mathrm{s}$ wind $37 \mathrm{~dB}(\mathrm{~A})$. Wind speeds should be measured at $10 \mathrm{~m}$ above ground, outside of residence, or location of concern

No noise limit has been imposed by the State. However, the State Site Evaluation Committee (SEC) has accepted a $45 \mathrm{~dB}(\mathrm{~A})$ setback on at least one project (e.g., Groton Wind Project; Groton, New Hampshire)

The State of Maine has Sound Level Limits for Routine Operation of Wind Energy Developments in Chapter 375 of Rule Chapters for the Department of Environmental Protection. The sound levels resulting from routine operation of a wind energy development shall not exceed (a) $75 \mathrm{~dB}$ (A) at any time of day at any property line of the wind energy development or contiguous property owned or controlled by the wind energy developer, whichever is farther from the proposed wind energy development's regulated sound sources; and (b) $55 \mathrm{~dB}(\mathrm{~A})$ between 7:00 a.m. and 7:00 p.m. (the "daytime limit"), and $42 \mathrm{~dB}(\mathrm{~A})$ between 7:00 p.m. and 7:00 a.m. (the "nighttime limit") at any protected location 
Table 2 | Review of reported wind turbine IS emissions (reported after 2010 ${ }^{\mathrm{a}}$ ).

\begin{tabular}{|c|c|c|c|c|c|c|c|}
\hline Author & Reference & $\begin{array}{c}\text { WT rated } \\
\text { power }\end{array}$ & Distance (m) & IS & Overall sound level & Background sound level & $\begin{array}{c}\text { Wind } \\
\text { speed }(\mathrm{m} / \mathrm{s})\end{array}$ \\
\hline \multirow[t]{2}{*}{ Ambrose et al. } & $(51)$ & 1.65 & 520 & $51-64 \mathrm{~dB}(\mathrm{G})$ indoor & $18-24 \mathrm{~dB}(\mathrm{~A})$ indoor & 39-44 dB(G) indoor & $6-20$ \\
\hline & & & & 54-65 dB(G) outdoor & $41-46 \mathrm{~dB}(\mathrm{~A})$ outdoor & 49-54 dB(G) outdoor & \\
\hline Boczar et al. & $(41)$ & 2 & 131 & 55-70 dB SPL outdoor & Not reported & Not reported & $1-8$ \\
\hline \multirow[t]{5}{*}{ Turnbull et al. } & $(43)$ & 2.1 & 85 & $72 \mathrm{~dB}(\mathrm{G})$ outdoor & Not reported & Not reported & $6-8$ \\
\hline & & & 185 & $67 \mathrm{~dB}(\mathrm{G})$ outdoor & & & \\
\hline & & & 360 & $61 \mathrm{~dB}(\mathrm{G})$ outdoor & & & \\
\hline & & 2 & 100 & $66 \mathrm{~dB}(\mathrm{G})$ outdoor & Not reported & $62 \mathrm{~dB}(\mathrm{G})$ outdoor & \\
\hline & & & 200 & $63 \mathrm{~dB}(\mathrm{G})$ outdoor & & & \\
\hline \multirow[t]{4}{*}{ Evans et al. } & $(44)$ & 2.1 & 1500 & $49-56 \mathrm{~dB}(\mathrm{G})$ indoor & Not reported & $51-55 \mathrm{~dB}(\mathrm{G})$ indoor & $10-12$ \\
\hline & & & & 57-61 dB(G) outdoor & Not reported & 58-60 dB(G) outdoor & \\
\hline & & 2.1 & 1400 & $57-66 \mathrm{~dB}(\mathrm{G})$ indoor & Not reported & Not reported & \\
\hline & & & & 56-62 dB(G) outdoor & Not reported & Not reported & \\
\hline \multirow[t]{2}{*}{ Evans } & $(45)$ & 3 & 1800 & $40-70 \mathrm{~dB}(\mathrm{G})$ indoor & Not reported & $45-60 \mathrm{~dB}(\mathrm{G})$ & $1-18$ \\
\hline & & & 2700 & $45-70 \mathrm{~dB}(\mathrm{G})$ indoor & Not reported & $45-70 \mathrm{~dB}(\mathrm{G})$ & $1-22$ \\
\hline
\end{tabular}

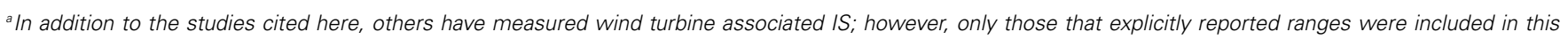
table.

Table 3 | Review of reported wind turbine LFN emissions (reported after $2010^{a}$ ).

\begin{tabular}{|c|c|c|c|c|c|c|c|}
\hline Author & Reference & WT rated power & Distance (m) & LFN & Overall sound level & Background sound level & Wind speed $(\mathrm{m} / \mathrm{s})$ \\
\hline \multirow[t]{5}{*}{ O’Neal et al. } & $(42)$ & 2.3 & 305 & $63.5 \mathrm{~dB}(\mathrm{C})$ outdoor & $49.4 \mathrm{~dB}(\mathrm{~A})$ outdoor & Nor reported & 3.3 \\
\hline & & & 323 & $54.7 \mathrm{~dB}(\mathrm{C})$ indoor & $33.8 \mathrm{~dB}(\mathrm{~A})$ indoor & & 3.2 \\
\hline & & 1.5 & 290 & $47.1 \mathrm{~dB}(\mathrm{C})$ indoor & $27.1 \mathrm{~dB}(\mathrm{~A})$ indoor & Not reported & 6.2 \\
\hline & & & 305 & $62.8 \mathrm{~dB}(\mathrm{C})$ outdoor & $50.7 \mathrm{~dB}(\mathrm{~A})$ outdoor & & 3.3 \\
\hline & & & 312 & $50.6 \mathrm{~dB}(\mathrm{C})$ indoor & $33.6 \mathrm{~dB}(\mathrm{~A})$ indoor & & 6.4 \\
\hline \multirow[t]{2}{*}{ Evans et al. } & (46) & 2.1 & 1500 & $0-4 \mathrm{~dB}(\mathrm{~A})$ indoor & NA & $3-8 \mathrm{~dB}(\mathrm{~A})$ indoor & $10-12$ \\
\hline & & & & $21-25 \mathrm{~dB}(\mathrm{~A})$ outdoor & & $22-29 \mathrm{~dB}(\mathrm{~A})$ outdoor & \\
\hline
\end{tabular}

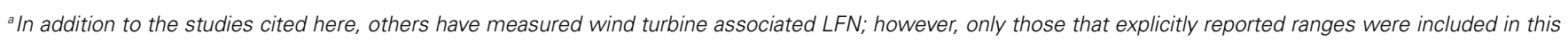
table.

carried out outdoors at $4.5 \mathrm{~m}$ height, and at a distance between 400 and $800 \mathrm{~m}$. Meteorological data were also recorded at a height of $10 \mathrm{~m}$ at the same location. The sound measurements were carried out using Class 1 instrumentation with sufficiently low noise floor. A large $450 \mathrm{~mm}$ diameter spherical secondary windscreen was employed in addition to a commercially available $7 \mathrm{~cm}$ primary wind screen to minimize pseudo-noise from wind flowing over the microphone. Field sound measurements of wind turbines are highly susceptible to contamination from extraneous noise such as from human activity, fauna, insects, and wind-induced noise. To control for these sources of contamination, the following methods were used:

- sound measurements were only collected during nighttime, between 10 p.m. and 5 a.m.;

- measurements were conducted in 1 min intervals;

- measurements were binned by wind speed for each $1 \mathrm{~min}$ interval;
- intervals within $1 \mathrm{~h}$ of rainfall or snowfall were not used; and

- intervals with gusty winds $(>2 \mathrm{~m} / \mathrm{s}$ above the mean wind speeds) were not used as these periods are more susceptible to wind-induced pseudo-noise.

Measurements were carried out in the vicinity of the wind facility during wind turbine operation as well as with the turbines off. The same filtering and data quality management methods were applied to both data sets. A minimum of 60 data points in each wind bin were gathered. To isolate only the LFN portion of the spectrum, data between 20 and $200 \mathrm{~Hz}$ were analyzed and summed. Once tallied, the mean spectrum for the 3 and $6 \mathrm{~m} / \mathrm{s}$ integer wind speeds was calculated. For each of those cases, the calculation was made from spectra where the mean wind speeds were within $0.5 \mathrm{~m} / \mathrm{s}$ of the stated value and was relatively steady during the entire interval. The gust filtering ensures that no gust was more than $2 \mathrm{~m} / \mathrm{s}$ above the mean. The mean spectrum was calculated by computing the energy averaged sound level for each $1 / 3$ rd octave band 
between 20 and $200 \mathrm{~Hz}$, and then computing an A-weighted sum of the spectrum.

The self-noise emitted by the system itself was assessed using the measurements conducted during periods when the wind turbines in the vicinity were not operating. The mean spectrum at various wind speeds was compared to those found in other literature comparing measured ambient levels with respect to wind speed. The most applicable study, conducted by the Japanese Ministry of Environment and reported by Tachibana (53) compared sound levels measured with various windscreens ranging from naked microphone to a specialized dodecahedron double windscreen. Measured low-frequency levels were at or below those reported in the double windscreen case in the Japanese study for most wind speeds and locations. It should be noted that although the measured ambient levels are consistent with those measured with high degree of windscreen protection, pseudo-noise contamination of the signal cannot be fully avoided.

Based on the measurements conducted, the typical measured $\mathrm{SD}$ for the A-weighted level was $\pm 3 \mathrm{~dB}$ for the turbines $\mathrm{ON}$, and $\pm 2 \mathrm{~dB}$ when the turbines were OFF. The SD was higher at lower wind speeds and decreased with increasing wind speed. This is due to wind-induced ambient noise (which is fairly steady) dominating the signal at the higher wind speed. At lower wind speeds, because the ambient levels are lower, individual nonturbine related events such as vehicular traffic, faunal noise, or other intermittent noises increase the variability in background noise. Additionally, during lower wind speeds, the wind turbine noise source would be more susceptible to changes in wind speed at the hub. For example, for two cases where the ground level wind speed is $3 \mathrm{~m} / \mathrm{s}$, the hub height wind speed could be $4 \mathrm{~m} / \mathrm{s}$ in one case and $8 \mathrm{~m} / \mathrm{s}$ in another. This would result in a difference in the amount of noise produced by the turbine. It is the authors' view that given the above variability, wind turbine noise measurements at far field distances should carry a nominal uncertainty value of \pm 3 to $\pm 5 \mathrm{~dB}$.

\section{RESULTS AND DISCUSSION \\ INDOOR INFRASOUND MEASUREMENTS}

Infrasound levels in the homes at $450 \mathrm{~m}$ were relatively similar, measuring 59 and $58 \mathrm{~dB}(\mathrm{G})$ (Table 4). IS measured at the furthest location of $900 \mathrm{~m}$ was comparable to the measurements at $450 \mathrm{~m}$, measuring $60 \mathrm{~dB}(\mathrm{G})$. These data indicate that IS levels were relatively constant with increased distance from the nearest wind turbine and were approximately $25 \mathrm{~dB}$ below the level of human perception [approximately $95 \mathrm{~dB}(\mathrm{G})$ (54)], which may be indicative of non-wind turbine associated distant sources of IS. The results reported here are consistent with previous measurements at varying distances (41-45). For instance, IS measurements from 290 to $323 \mathrm{~m}$ from wind turbines were $20-30 \mathrm{~dB}$ below the human auditory threshold levels (42). Additional measurements of IS in the $1-30 \mathrm{~Hz}$ range at a distance of $200 \mathrm{~m}$ from the wind turbines also remained below the human auditory threshold (41). Other investigations have shown that at further distances $(1.5 \mathrm{~km})$ indoor IS levels in two residences were between 49 and $61 \mathrm{~dB}(\mathrm{G})$, with no reported difference between operational and shutdown periods, also suggesting that there are other sources of IS contributing to these results (44). The same group (55) also showed that indoor IS
Table 4 | Indoor infrasound measured at three homes at two different distances to $1.5 \mathrm{MW}$ turbines.

\begin{tabular}{lcc}
\hline WT rated power (MW) & Distance $(\mathbf{m})$ & IS level $[\mathbf{d B}(\mathbf{G})]$ \\
\hline 1.5 & 450 & 59 \\
1.5 & 450 & 58 \\
1.5 & 900 & 60 \\
\hline
\end{tabular}

Table 5 | Infrasound noise limits per jurisdiction (not wind turbine specific).

\begin{tabular}{lll}
\hline Country/region & Noise limits & Reference \\
\hline Australia/ & $\begin{array}{l}\text { G-weighting function used to } \\
\text { determine annoyance due to } \\
\text { infrasound within the frequency range } \\
\text { from } 1 \text { to } 20 \mathrm{~Hz} \text {. The recommended } \\
\text { limit value for infrasound inside } \\
\text { dwellings during the day, evening and } \\
\text { night is } 85 \mathrm{~dB}(\mathrm{G}) \text {. Noise is measured } \\
\text { over a 10-min period and a } 5 \mathrm{~dB} \text { penalty } \\
\text { is added for impulsive noise. } \\
\text { Approximate determination of sound } \\
\text { pressure level may be made by } \\
\text { analysis of the signal using one-third } \\
\text { octave bands and application of the } \\
\text { provided weighting values } \\
\text { The reference value for complaints of } \\
\text { mental and physical discomfort include } \\
\text { the G-weighted sound pressure level } \\
\text { of } 92 \mathrm{~dB}(\mathrm{G}) \text { as measured at } 10 \mathrm{~Hz}\end{array}$ \\
Japan
\end{tabular}

levels were between 50 and $70 \mathrm{~dB}(\mathrm{G})$ at distances of 1.8 and $2.7 \mathrm{~km}$ from the nearest wind farm. In conjunction with these reports, the results from the current field investigation indicate that wind turbines are a source of IS; however, sound levels are well below the human auditory threshold.

Only two jurisdictions have developed clear guidelines for IS and neither is specific to wind turbine noise (Table 5). This may be partly a result of the highly sophisticated equipment and analyses required to accurately measure IS and distinguish between the IS generated from wind turbines and other natural and engineered sources (56). The Queensland Department of Environment and Resource Management's Draft ECOACCESS Guideline-Assessment of Low Frequency Noise proposed an interior IS limit of $85 \mathrm{~dB}(\mathrm{G})$ (57). This value was derived based on a $10 \mathrm{~dB}$ protection level from the average $95 \mathrm{~dB}(\mathrm{G})$ hearing threshold (54) and previous Danish recommendations for IS limits (58). The Japanese Handbook on Low Frequency Noise provides an IS reference value of $92 \mathrm{~dB}(\mathrm{G})$ at $10 \mathrm{~Hz}$ and $1 / 3$-octave bands up to $80 \mathrm{~Hz}$ (59). These values were derived from investigations that monitored complaints of mental and physical discomfort from healthy adults exposed to low-frequency sounds in a room (59). Though the Japanese guidelines were derived through short-term monitoring experiments and are not equivalent to the long-term exposure associated with 
living in proximity of wind turbines, the levels of IS measured as part of this current study (Table 4) are 20-30 dB below these guidelines.

A limited number of reports have suggested that the IS component of wind turbine noise is the cause of self-reported adverse health effects $(51,60,61)$. Mechanisms within the inner ear that are sensitive to low levels of IS stimulation have been proposed to be associated with adverse health responses $(36,37,62)$. However, functional magnetic resonance imaging has provided powerful evidence that IS is perceived via similar auditory pathways as audible sounds when above the level of perception with no indication of cortical activation at sub-threshold values (63). Furthermore, exposure to IS is known to originate from other engineered or natural processes, including wind and weather systems (64), volcanic (65) and auroral activity (66), and mountain ranges (67); this would arguably also induce stimulation of the inner ear. Recent outdoor measurements have provided an indication of IS levels from a number of natural sources, including sea waves at $25 \mathrm{~m}$ from the coast $[75 \mathrm{~dB}(\mathrm{G})], 250 \mathrm{~m}$ from a coastal cliff face $[69 \mathrm{~dB}(\mathrm{G})]$ and $8 \mathrm{~km}$ inland from the coast $[57 \mathrm{~dB}(\mathrm{G})]$ (43). The authors reported that wind turbine IS levels, which were between 61 and $72 \mathrm{~dB}(\mathrm{G})$ at distances of $85-360 \mathrm{~m}$, were lower than many of the natural sources measured (43). IS is also generated in urban environments as a result of human activity and engineered sources such as industrial processes, ventilation systems, and vehicles $(43,44)$. Measurements of IS in a typical urban setting have been reported to be up to $70 \mathrm{~dB}(\mathrm{G})$ during the daytime and $63 \mathrm{~dB}(\mathrm{G})$ at night (44). In comparison, studies reporting biological responses to IS exposure were at sound pressure levels that were above the level of auditory perception, much higher than those produced by wind turbines [e.g., $145 \mathrm{~dB}$ and $165 \mathrm{~dB}$ (68, 69)]. Collectively, these reports and the measurements from the current investigation indicate that humans are regularly exposed to IS from several natural and engineered sources at levels that exceed those produced by wind turbines. Although sounds with impulsive characteristics (e.g., wind turbines) generate greater levels of annoyance than non-impulsive sources, annoyance levels have only been associated with noises that are above the threshold of auditory perception $(9,70)$. Our measurements of IS, and those from the literature, are all well below the threshold of auditory perception.

\section{OUTDOOR LOW-FREOUENCY NOISE AND OVERALL SOUND MEASURES}

Outdoor LFN levels were assessed through 1/3-octave band measurements with wind turbines operational (on) and during scheduled shutdown periods (off) at distances of 480, 490, 611, and $810 \mathrm{~m}$ (Figure 1). The most evident result is the similarity between measured LFN levels with wind turbines on and off (ambient) from 20 to $100 \mathrm{~Hz}$, at which point sound levels began to deviate from one another. This deviation was most apparent at measurements taken nearest the turbines (Figures 1A,B) where levels of LFN from turbines on differed from ambient by 6 and $9 \mathrm{~dB}$ at wind speeds of 3 and $6 \mathrm{~m} / \mathrm{s}$, respectively. As distance from the turbines increased, the amount by which LFN levels measured with turbines on and off differed compared those observed at $480 \mathrm{~m}$. At 490 and $611 \mathrm{~m}$, the maximum difference between on and off was between 3 and $4 \mathrm{~dB}$. At the furthest observation point of $810 \mathrm{~m}(3 \mathrm{~m} / \mathrm{s})$, there was no difference in LFN levels measured during wind turbine operation and shutdown (Figure 1G). At lower frequencies within the LFN spectrum $(20-100 \mathrm{~Hz})$, the contribution of the wind turbines was negligible when compared to ambient levels at distances $\geq 490 \mathrm{~m}$ (Figures 1C-G). At all distances and wind speeds, irrespective of wind turbine operation, LFN exceeded the ISO-defined audible threshold at frequencies $>40-50 \mathrm{~Hz}$ (71). These results indicate that the observed increase in LFN during wind turbine operation was found primarily in the frequency range consistent with the audible range of hearing, namely $20-20,000 \mathrm{~Hz}$, and not in the IS range $(<20 \mathrm{~Hz})$. It is also noted that the same applies to ambient noise levels, namely that the levels cross the auditory threshold at frequencies between 40 and $50 \mathrm{~Hz}$ and higher.

Through the 1/3-octave band analysis of overall sound levels (20-20,000 Hz; Figure 2), it was apparent that the increase in LFN from wind turbine operation was accompanied by increased sound levels at higher frequencies (i.e., $>200 \mathrm{~Hz}$ ). This was particularly evident at $480 \mathrm{~m}$ where wind turbine associated sound levels continued to be above ambient levels until approximately $3150 \mathrm{~Hz}$ (Figures 2A,B). At further distances, sound levels were above ambient levels at frequencies between 125 and $1000 \mathrm{~Hz}$, but not easily distinguishable from ambient levels below $125 \mathrm{~Hz}$ or above $1 \mathrm{kHz}$ (Figures 2C-F). These results indicate that though there was an observed increase in LFN levels during wind turbine operation at the $480 \mathrm{~m}$ location this increase was accompanied by an increase in sound levels up to $3 \mathrm{kHz}$.

At closer distances where the LFN component can be measured above the ambient conditions, the mid frequency sound levels were also above ambient levels. In those cases, the signalto-noise ratio of the mid frequency sound levels was higher than that below $125 \mathrm{~Hz}$, indicating that the most audible portion of the frequency spectrum was between 125 and $3150 \mathrm{~Hz}$. At further distances, it was evident that the signal-to-noise ratio decreased, such that only acoustic energy between $125 \mathrm{~Hz}$ and about 800 $1000 \mathrm{~Hz}$ was above background, with the highest signal-to-noise ratio between 200 and $500 \mathrm{~Hz}$ (Figures 2C-F). The single measurement point at $810 \mathrm{~m}$ showed no measurable increase in any of the mean sound levels. This is indicative that a presence of LFN in the signal from wind turbines was accompanied by a presence in mid frequency sound levels. For instance, where the LFN levels were considerably above ambient levels, the mid frequency sounds levels were also considerably increased. This indicates that, at the distances of interest, it is the mid frequency region that is the most audible portion of the noise from the turbines. Only at closer distances, where the mid frequency components would be clearly audible (6-9 $\mathrm{dB}$ signal-to-noise ratio), would the lowfrequency components from the turbines start to be audible above ambient levels. The overall A-weighted sound pressure level was significantly affected by the mid frequency component. As a result, it would be expected that by controlling the overall sound pressure level $[\mathrm{dB}(\mathrm{A})]$ from normal functioning wind turbines that the LFN component would also mitigated.

When the wind turbines were operating, the highest mean LFN level $[\mathrm{dB}(\mathrm{A})]$ was observed at $480 \mathrm{~m}$ (Table 6). At the other locations $>480 \mathrm{~m}$ from the wind turbines, the measured difference between wind turbines on and off was between 1 and $3 \mathrm{~dB}$, at 


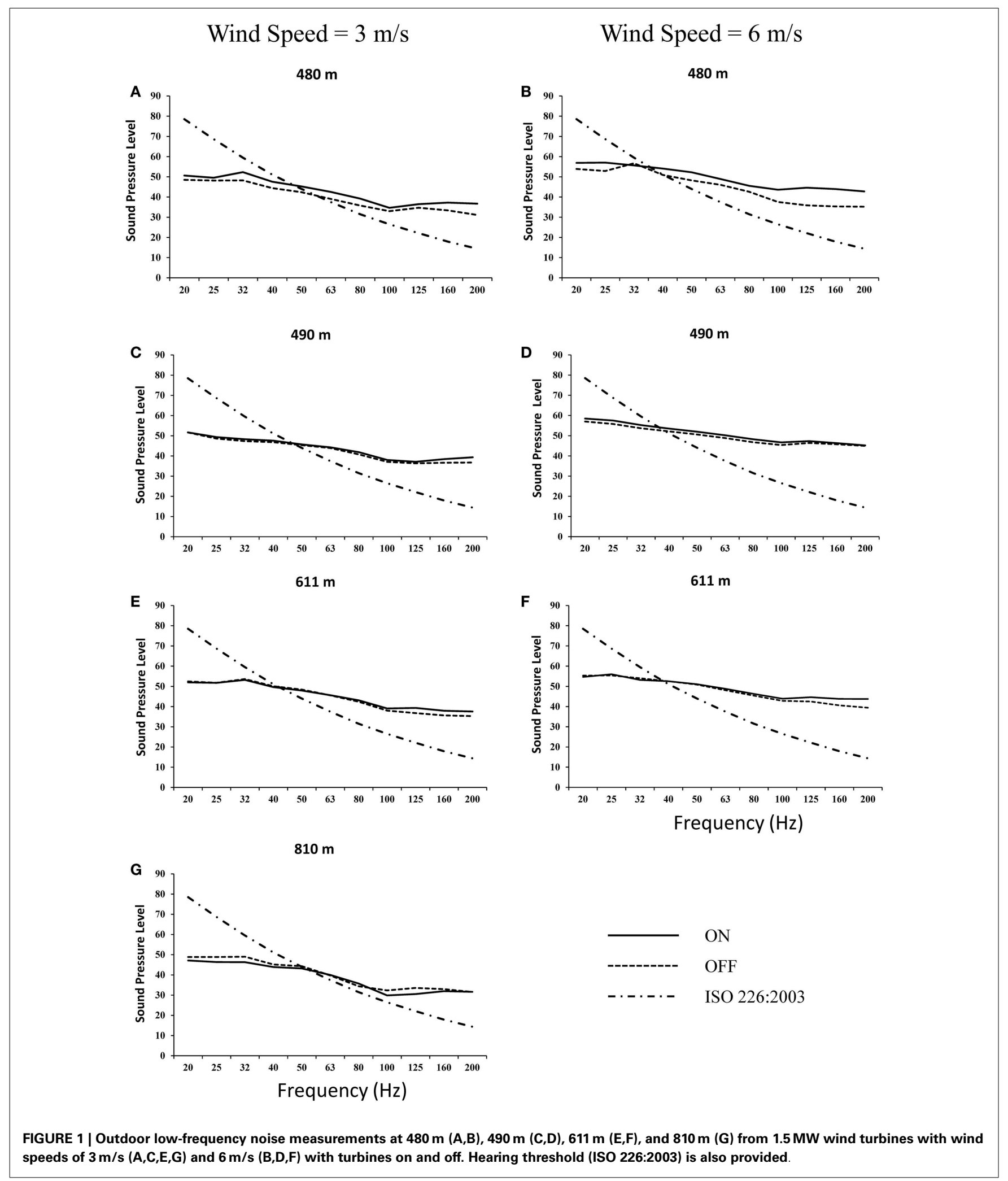

least half of that observed at $480 \mathrm{~m}$. The mean overall sound levels reported in $\mathrm{dB}(\mathrm{A})$ showed very similar trends to those reported in the LFN analysis. Critically, the increase in mean sound levels at the closest location $(480 \mathrm{~m})$ reported in the LFN spectrum and overall sound in the 1/3-octave band analysis was maintained. In addition, the observed trends at 490,611, and $810 \mathrm{~m}$, also remained 


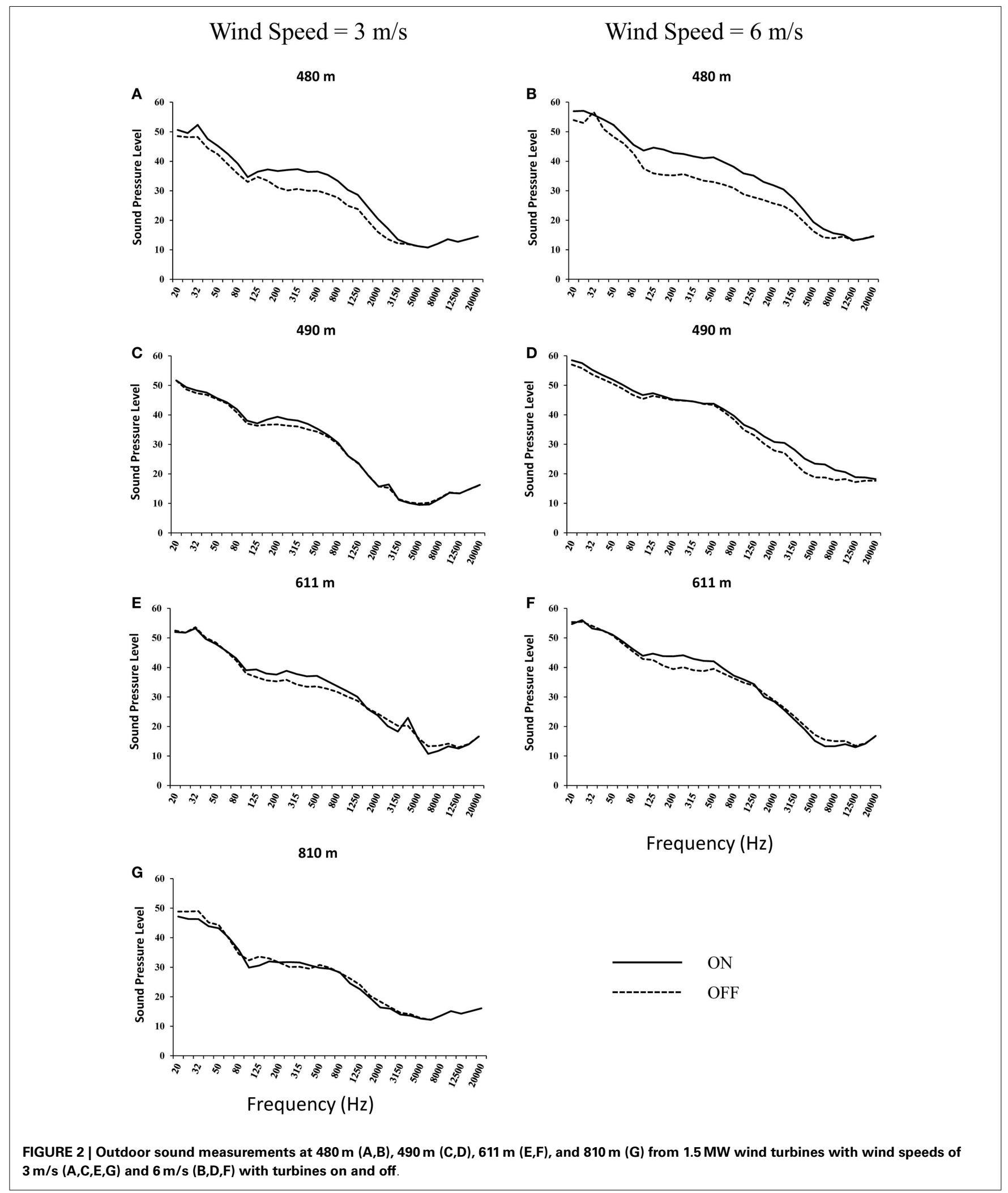

consistent. From these results, it is evident that during wind turbine operation, the increased sound levels that began in the LFN spectrum, at approximately $160 \mathrm{~Hz}$ and continued to $1000 \mathrm{~Hz}$, were above auditory threshold levels and represented in the mean $\mathrm{dB}(\mathrm{A})$ sound measures. The consistency between the mean $\mathrm{dB}(\mathrm{A})$ measurements and trends observed in the $1 / 3$-octave band analysis 
suggest that the contribution of the LFN component and overall sound levels were accounted for in the calculation.

A number of investigations have reported LFN levels in the proximity of wind turbines (Table 2) similar to those reported here. Furthermore, the results showing LFN levels passing the auditory threshold between 40 and $50 \mathrm{~Hz}$ are similar to those that have been previously reported $(42,72)$. For instance, O'Neal

\begin{tabular}{|c|c|c|c|c|c|}
\hline $\begin{array}{l}\text { Wind } \\
\text { speed }(\mathrm{m} / \mathrm{s})\end{array}$ & Distance (m) & LFN “On” & LFN “Off” & $\begin{array}{l}\text { Overall } \\
\text { sound } \\
\text { "On” }\end{array}$ & $\begin{array}{l}\text { Overal } \\
\text { sound } \\
\text { "Off"a }\end{array}$ \\
\hline \multirow[t]{4}{*}{3} & 480 & 30 & 26 & 41 & 35 \\
\hline & 490 & 32 & 30 & 40 & 39 \\
\hline & 611 & 31 & 30 & 42 & 40 \\
\hline & 810 & 25 & 26 & 36 & 36 \\
\hline \multirow[t]{3}{*}{6} & 480 & 36 & 30 & 47 & 40 \\
\hline & 490 & 39 & 38 & 49 & 48 \\
\hline & 611 & 37 & 34 & 49 & 45 \\
\hline
\end{tabular}

${ }^{a}$ Ambient noise at this location, with turbines off, is influenced by wind speed $(3$ and $6 \mathrm{~m} / \mathrm{s}$ ) and movement of vegetation in the measuring location. et al. (42) measured indoor and outdoor LFN levels from wind turbines at a distance of $300 \mathrm{~m}$ and found the levels were below the United Kingdom's (UK) Department for Environmental and Rural Affairs (DEFRA) and Japanese guidelines and became audible at approximately $50 \mathrm{~Hz}$ (42). Elsewhere, LFN levels were only marginally higher and remained well below guidelines even though measurements were taken as close as $104 \mathrm{~m}$ from the nearest wind turbine (72). LFN measured at 1.8 and $2.7 \mathrm{~km}$ from the nearest wind farm was comparable during pre-operational and operational periods of development, though small increases at frequencies above $63 \mathrm{~Hz}$ were reported (45). At a greater distance of $1.5 \mathrm{~km}$ from wind turbines, Evans et al. found LFN levels were similar to those measured at distances of 10 and $30 \mathrm{~km}$ from the turbines (46). Further, organized shut downs of the two wind farms showed that the contributions of the turbines to LFN measurements were negligible or relatively small contributions at $100 \mathrm{~Hz}$ and above (46). As shown with IS, LFN is also produced by natural and common engineered sources: in urban environments, including offices and residences, LFN levels often exceed available guidelines and are greater than those measured $1.5 \mathrm{~km}$ from the nearest wind turbine (46).

The sound characteristics and associated fall off with distance have been extensively measured by Tachibana in the range from $0.8 \mathrm{~Hz}$ to $5 \mathrm{kHz}$ at 164 locations around 29 wind farms, using one third octave analysis. The average of the measures fell with a slope of $4 \mathrm{~dB}$ /octave over the whole range. The average passed

Table 7 | Indoor LFN noise limits per jurisdiction (not wind turbine specific).

\begin{tabular}{|c|c|}
\hline Country/region & Noise limits \\
\hline $\begin{array}{l}\text { Australia/ } \\
\text { Queensland }\end{array}$ & $\begin{array}{l}\text { Overall sound pressure level inside residences should not exceed } 50 \mathrm{~dB} \text { (linear). If the dB (linear) measurement } \\
\text { exceeds the } \mathrm{dB}(\mathrm{A}) \text { measurement by more than } 15 \mathrm{~dB} \text { further analysis of one-third octave band between } 20 \text { and } \\
200 \mathrm{~Hz} \text { is suggested. Recommended limits for non-tonal low-frequency noise in a dwelling, during the evening and } \\
\text { night is } 20 \mathrm{~dB}(\mathrm{~A}) \text { and during the day } 25 \mathrm{~dB}(\mathrm{~A})\end{array}$ \\
\hline Denmark & $\begin{array}{l}\text { Low-frequency noise limits are limited to a total level of } 20 \mathrm{~dB}(\mathrm{~A}) \text { indoors as measured by the A-weighted level of } \\
\text { noise in } 1 / 3 \text {-octave bands between } 10 \text { and } 160 \mathrm{~Hz}\end{array}$ \\
\hline Japan & $\begin{array}{l}\text { Reference values for complaints of mental and physical discomfort are provided in 1/3-octave sound pressure levels } \\
\text { from } 10 \text { to } 80 \mathrm{~Hz} \text {. The handbook suggests taking sound pressure level and G-weighted sound pressure levels. The } \\
\text { guidelines provided by the handbook are only applicable to LFN produced by stationary sound sources that produced } \\
\text { LFN continuously and is not applicable to LFN from transient and intermittent sources such as airplanes, railways, or } \\
\text { explosive blasts. Values for mental and physical complaints were based on an investigation of tolerable levels of } \\
\text { low-frequency noise from which a } 10 \text { percentile curve was developed }\end{array}$ \\
\hline Poland & $\begin{array}{l}\text { "Criteria were based on the measurement data of annoying noises, investigation of the effects of noise on the health } \\
\text { of the exposed inhabitants, laboratory tests of thresholds of narrow and broad-band noise perception and a review of } \\
\text { the present literature. In order to assess the noise spectra measured in dwellings, the A } 10 \text { characteristic has been } \\
\text { accepted as the rating curve. Its levels, L, for } 1 / 3 \text {-octave bands are determine by the relation La } 10=10-K a, \text { where Ka } \\
\text { is the A-weighting. Low-frequency noise is annoying when the sound pressure levels of the noise exceed the A10 } \\
\text { curve and simultaneously exceed the background noise level by more than } 10 \mathrm{~dB} \text { for tonal noise and by } 6 \mathrm{~dB} \text { for } \\
\text { broad-band noise" }\end{array}$ \\
\hline
\end{tabular}

Reference

United Indoor recordings of Leq, L10 and L90 in third octave bands between 10 and $160 \mathrm{~Hz}$ should be made. If the Leq Kingdom exceeds values provided then it may indicate a significant source of LFN that could be causing disturbances. If the noise only occurs during the day then a $5 \mathrm{~dB}$ relaxation may be applied. If the noise is steady then a $5 \mathrm{~dB}$ relaxation may be applied. Reference curve was developed based on protective value of $5 \mathrm{~dB}$ below the average threshold of hearing 
through $55 \mathrm{~dB}$ at $10 \mathrm{~Hz}$ and crossed the hearing threshold at about $50 \mathrm{~Hz}$ (73). Other, less detailed measurements on individual turbines have shown slopes of $5 \mathrm{~dB}$ /octave to $6 \mathrm{~dB}$ /octave (42). A spectrum, which falls at $5 \mathrm{~dB}$ /octave and passes through, for example, $60 \mathrm{~dB}$ at $10 \mathrm{~Hz}$ has an A-weighted level of $39 \mathrm{~dB}(\mathrm{~A})$, which is mainly determined by a broad peak in the A-weighted spectrum in the region of $200 \mathrm{~Hz}$ to $630 \mathrm{~Hz}$. Any shift in the level at $10 \mathrm{~Hz}$ is reflected in the A-weighted level. Similarly, this spectrum has a $\mathrm{C}$-weighted level of $58 \mathrm{~dB}(\mathrm{C})$. The difference between $\mathrm{dB}(\mathrm{A})$ and $\mathrm{dB}(\mathrm{C})$ levels depends only on the spectrum shape and is independent of overall level, indicating that for similar spectrum shapes, the $\mathrm{dB}(\mathrm{A})$ and $\mathrm{dB}(\mathrm{C})$ levels are highly correlated.

There are currently no widely accepted international healthbased limits for LFN specifically derived for wind turbines. A number of jurisdictions have developed both indoor and outdoor LFN limits to address potential issues associated with industrial noise emissions (Tables 7 and 8 ). The majority of the limits are for indoors and utilize 1/3-octave sound pressure level measurements between 5 and $200 \mathrm{~Hz}$. This analysis enables assessors to identify tonal components within the spectrum that may be problematic. The 1/3-octave band limits vary significantly between jurisdictions. In Poland, LFN limits are around $10 \mathrm{~dB}(\mathrm{~A})$ across $1 / 3$-octave bands between 10 and $250 \mathrm{~Hz}$ (74). In Denmark, LFN is limited to a total level of $20 \mathrm{~dB}(\mathrm{~A})$ between 10 and $160 \mathrm{~Hz}(75)$, while in UK, guidelines are generally between 10 and $25 \mathrm{~dB}(\mathrm{~A})$ depending on the frequency between 10 and $100 \mathrm{~Hz}$ (76). Indoor LFN limits provide a basis to address specific complaints from local residents; however, for wind farm development, regular monitoring of outdoor sound levels presents a more practical option.

Only a small number of jurisdictions, including the province of Alberta, Canada (24), Japan (59), and Australian States of South Australia and New South Wales (18), have introduced outdoor LFN noise limits (Table 8). Several of these guidelines determine the difference between $\mathrm{C}$ - and A-weighted sound measurements $(19,24,77)$. This calculation can provide an indication of an unbalanced spectrum; a difference $>20 \mathrm{~dB}$ between two weightings may warrant further investigation based on those regulations $(78,79)$. The ability of this calculation to predict LFN issues is limited, particularly when there are low levels of background noise that result in a large difference between the A- and C-weighted sound levels that are not associated with increased levels of annoyance (80). In the current investigation the difference between wind turbine operational scenarios (i.e., on and off) was $<5 \mathrm{~dB}$ at the 490 and $611 \mathrm{~m}$ locations at both wind speeds. Measured background levels at 490 and $611 \mathrm{~m}$ were also high, measuring 48 and $45 \mathrm{~dB}(\mathrm{~A})$, respectively. A number of noise guidelines, including those in UK (32), New Zealand (23), and several of the Australian states $(18-20,22)$, take into account the potential for high levels of background noise by suggesting that the contribution of wind turbines to be limited to $<5 \mathrm{~dB}$ above background. In the current

Table 8 | Outdoor LFN noise limits per jurisdiction (not wind turbine specific).

\begin{tabular}{|c|c|}
\hline Country/region & Noise limits \\
\hline Australia/New & Considered it unnecessary to establish the full spectral signature of all wind turbines based on the findings that wind \\
\hline \multirow[t]{7}{*}{ South Wales } & turbines have very similar spectral signatures and do not generate excessive levels of low-frequency noise. \\
\hline & Recommended using $\mathrm{dB}(\mathrm{C})$ measurements at intermediate locations to identify any anomalies such as a mechanical \\
\hline & problem or a need for any further investigation. "Trigger levels of $65 / 60 \mathrm{~dB}(\mathrm{C})$ as suggested by Broner (2011) were \\
\hline & adopted" " $5 \mathrm{~dB}(\mathrm{~A})$ penalty should be applied to the predicted or measured noise level from the wind farm for the \\
\hline & periods and meteorological conditions under which the low-frequency noise has been identified." New South Wales \\
\hline & Industrial Noise Policy (1999) suggests that a difference of $15 \mathrm{~dB}$ or greater between $\mathrm{dB}(\mathrm{A})$ and $\mathrm{dB}(\mathrm{C})$ weightings can \\
\hline & establish the presence of a low-frequency noise can be established and addressed \\
\hline
\end{tabular}

Australia/South Follow the suggestions made by the New South Wales Industrial Noise Policy, but do not provide any specific limit or Australia required actions

Canada/Alberta A LFN issue exists both when " $(A)$ the time-weighted $d B(C)-d B(A)$ value for the measured daytime or nighttime period is $\geq 20 \mathrm{~dB}$ and $(B) A$ clear tonal component exists at a frequency between 20 and $250 \mathrm{~Hz}$." When a LFN issue has been identified, measurements of C- and A-weighted scales are to be made concurrently. The presence of a LFN issue is confirmed when both " $(A)$ The isolated time-weighted average $d B(C)-d B(A)$ value for the measured daytime or nighttime period is $\geq 20 \mathrm{~dB}$. For the $1 / 3$-octave frequency bands between 20 and $250 \mathrm{~Hz}$ and below: (a) the linear sound level of one band must be at least $10 \mathrm{~dB}$ or more above one of the adjacent bands within two one-third octave bandwidths (b) there must be at least a five $\mathrm{dB}$ drop in level within two bandwidths on the opposite side of the frequency band exhibiting the high sound levels." If these conditions exist, " $5 \mathrm{~dB}(\mathrm{~A})$ must be added to the measured comprehensive sound level. If this value exceeds the permissible sound level, the licensee must identify the source of the LFN and implement noise attenuation measures to address the issue in a timely way" 
investigation, the $480 \mathrm{~m}$ location was the only one observed to be $\geq 5 \mathrm{~dB}$ above background levels $(6 \mathrm{~dB}$ at $3 \mathrm{~m} / \mathrm{s}$ and $7 \mathrm{~dB}$ at $6 \mathrm{~m} / \mathrm{s})$.

\section{CONCLUSION}

Data from the current investigation indicate that wind turbines produce noise that is broad-band in nature, which includes energy within the IS and LFN spectrums. Based on the data presented here, the indoor IS component of wind turbine noise measured as $\mathrm{dB}(\mathrm{G})$ at distances of 450 and $900 \mathrm{~m}$, was well below the levels of human perception (54), providing further support to previous reports $(39,41-45,81)$. IS is produced at levels comparable or greater than those shown here by natural and engineered sources $(43,81)$. There is no scientific evidence to indicate that exposure at these G-weighted levels of IS can directly impact human health. Recent studies have indicated that psychological factors $(12,13)$ and the manner in which information is presented from media reports and non-scientific sources may influence the perception and expectations associated with wind turbine sounds (82). These reports suggest that subjective variables may be a more likely etiology for self-reported effects than from exposure to IS associated with normal wind turbine operation.

The LFN analysis showed that when the turbines were both on and off sounds above $40-50 \mathrm{~Hz}$ exceeded the threshold for auditory perception as defined by ISO 226:2003 (71). A clear contribution from the operation of the wind turbines was only observed at the closest location of $480 \mathrm{~m}$ when compared to background levels. Increases in LFN observed between 100 and $200 \mathrm{~Hz}$ corresponded to increases in overall sound measures reported in $\mathrm{dB}(\mathrm{A})$. The use of alternative sound weightings [i.e., $\mathrm{dB}(\mathrm{C})]$ may have utility in instances where there are significant increased levels of LFN, particularly when a tonal component is present. However, the results from the current investigation indicate that increases in LFN associated with wind turbine operation are correlated with increases in overall sound levels. These results, in conjunction with those of previous reports, suggest that controlling for overall sound levels produced by normally operating wind turbines will inherently control for LFN $(38,48,77)$. The results reported here are in agreement with a recent report issued by Health Canada, which concluded that following over $4,000 \mathrm{~h}$ of wind turbine noise measurements, there was "no additional benefit in assessing LFN as $C$ - and A-weighted levels were so highly correlated $(r=0.94)$ that they essentially provided the same information" (50). Given the low levels of IS and the correlation between LFN and overall sound levels from wind turbines, the development and enforcement of suitable outdoor guidelines and limits, based on $\mathrm{dB}(\mathrm{A})$, provide an effective means to evaluate, monitor, and protect potential receptors.

\section{AUTHOR CONTRIBUTIONS}

All authors contributed equally to the conception and design of the analysis; PA performed the field measurements and analyzed the data; RB wrote the manuscript with contributions from all other authors.

\section{ACKNOWLEDGMENTS}

The authors would like to acknowledge Rebecca Morrison for her help with quality control of the tables.

\section{REFERENCES}

1. World Health Organization (WHO). Energy, sustainable development and health. Fourth Ministerial Conference on Environment and Health. Budapest (2004).

2. Wiser R, Bolinger M. 2012 Wind Technologies Market Report. US Department of Energy (2013). Available from: http://www.windpoweringamerica.gov/pdfs/ 2012_annual_wind_market_report.pdf

3. Independent Electricity System Operator (IESO). Ontario's Supply Mix. Available from: http://ieso-public.sharepoint.com/Pages/Ontario\%27s-PowerSystem/Supply-Mix/default.aspx\#Wind

4. Wolsink M. Wind power and the NIMBY-myth: institutional capacity and the limited significance of public support. Renew Energy (2000) 21:49-64. doi:10.1016/S0960-1481(99)00130-5

5. Jobert A, Laborgne P, Mimler S. Local acceptance of wind energy: factors of success identified in French and German case studies. Energy Policy (2007) 35:2751-60. doi:10.1016/j.enpol.2006.12.005

6. Baxter J, Morzaria R, Hirsch R. A case-control study of support/opposition to wind turbines: perceptions of health risk, economic benefits, and community conflict. Energy Policy (2013) 61:931-43. doi:10.1016/j.enpol.2013.06.050

7. McCallum LC, Aslund ML, Knopper LD, Ferguson GM, Ollson CA. Measuring electromagnetic fields (EMF) around wind turbines in Canada: is there a human health concern? Environ Health (2014) 13:9. doi:10.1186/1476-069X-13-9

8. Knopper LD, Ollson CA. Health effects and wind turbines: a review of the literature. Environ Health (2011) 10:1-10. doi:10.1186/1476-069X-10-78

9. Pedersen E, Persson Waye K. Perception and annoyance due to wind turbine noise - a dose-response relationship. J Acoust Soc Am (2004) 116:3460-70. doi:10.1121/1.1815091

10. Pedersen E, Persson Waye K. Wind turbine noise, annoyance and self-reported health and well-being in different living environments. Occup Environ Med (2007) 64:480-6. doi:10.1136/oem.2006.031039

11. Chapman S, St George A. How the factoid of wind turbines causing 'vibroacoustic disease' came to be 'irrefutably demonstrated'. Aust N Z J Public Health (2013) 37:244-9. doi:10.1111/1753-6405.12066

12. Crichton F, Dodd G, Schmid G, Gamble G, Cundy T, Petrie KJ. Can expectations produce symptoms from infrasound associated with wind turbines? Health Psychol (2013) 33:360-4. doi:10.1037/a0031760

13. Crichton F, Dodd G, Schmid G, Gamble G, Cundy T, Petrie KJ. The power of positive and negative expectations to influence reported symptoms and mood during exposure to wind farm sound. Health Psychol (2013) 33:1588-92. doi: $10.1037 /$ hea 0000037

14. Ellenbogen JM, Grace S, Heiger-Bernays W, Manwell J, Mills D, Sullivan K, et al. Wind Turbine Health Impact Study: Report of Independent Expert Panel. Boston, MA: Massachusetts Department of Environmental Protection (MassDEP) and Massachusetts Department of Public Health (MDPH) (2012). Available from: http://www.mass.gov/eea/docs/dep/energy/wind/turbine-impact-study.pdf

15. Merlin T, Newton S, Ellery B, Milverton J, Farah C. Systematic Review of the Human Health Effects of Wind Farms. Canberra, ACT: National Health and Medical Research Council (2013). Available from: https://www.nhmrc.gov. au/_files_nhmrc/publications/attachments/eh54_systematic_review_of_the_ human_health_effects_of_wind_farms_december_2013.pdf

16. Knopper L, Ollson CA, McCallum L, Whitfield Aslund M, Berger RG, Souweine K, et al. Wind turbines and human health. Front Public Heath (2014) 2:63. doi:10.3389/fpubh.2014.00063

17. World Health Organization (WHO). Night Noise Guidelines for Europe. Copenhagen: The Regional Office for Europe of the World Health Organization (2009). Available from: http://www.euro.who.int/_data/assets/pdf_file/0017/ 43316/E92845.pdf

18. New South Wales Planning and Infrastructure. NSW Planning Guidelines: Wind Farms. Draft for Consultation. Sydney, NSW: NSW Department of Planning and Infrastructure (2011). Available from: http://www.planning.nsw.gov.au/LinkClick.aspx?fileticket=5yeY6yw_wRE\% $3 \mathrm{~d} \&$ tabid $=205 \& \mathrm{mid}=1081$ \&language $=\mathrm{en}-\mathrm{AU}$

19. South Australia Environmental Protection Authority. Wind Farms Environmental Noise Guidelines. Adelaide, SA: Environmental Protection Authority (2009). Available from: http://www.epa.sa.gov.au/xstd_files/Noise/Guideline/ windfarms.pdf

20. Western Australian Planning Commission. Guidelines for Wind Farm Development. Perth, WA: Department for Planning and Infrastructure (2004). Report No. 67. Available from: http://www.planning.wa.gov.au/dop_pub_pdf/ pb67May04.pdf 
21. Haugen KMB. International Review of Policies and Recommendations for Wind Turbine Setbacks from Residences: Setbacks, Noise, Shadow Flicker, and Other Concerns. St. Paul, MN: Minnesota Department of Commerce (2011). Available from: http://mn.gov/commerce/energyfacilities/documents/ International_Review_of_Wind_Policies_and_Recommendations.pdf

22. Department of Planning and Community Development. Policy and Planning Guidelines for Development of Wind Energy Facilities in Victoria. Melbourne, VIC: Victorian Government Department of Planning and Community Development (2012). Available from: http://www.dtpli.vic.gov.au/_data/ assets/pdf_file/0009/231768/Policy-and-planning-guidelines-for-development -of-wind-energy-facilities-in-Victoria-July-2012.pdf

23. New Zealand Wind Energy Association. The New Zealand Wind Farm Noise Standard. Wellington: The New Zealand Wind Energy Association (2010). Available from: http://www.windenergy.org.nz/store/doc/NZ_WindFarm_Noise_ Standard.pdf

24. Alberta Utilities Commission. Rule 012: Noise Control (2013). Available from: http://www.auc.ab.ca/rule-development/noise-control/Pages/default.aspx

25. Ministry of Forests, Lands and Natural Resource Operations, Ministry of Energy, Mines and Natural Gas, Environmental Assessment Office. Best Practice for Wind Power Project Acoustic Assessment British Columbia. Vancouver, BC: Ministry of Forests, Lands and Natural Resource Operations (2012). Available from: http://www.for.gov.bc.ca/land_tenures/tenure_programs/programs/ windpower/bmp_wind_acoustic.pdf

26. Manitoba Intergovernmental Affairs. Land use Planning for Wind Energy Systems in Manitoba. Winnipeg, MB: EDS Consulting (2009). Available from: http://www.gov.mb.ca/ia/plups/MobilePages/pdf/weg.pdf

27. New Brunswick Department of Energy. Model Wind Turbine Provisions and Best Practices for New Brunswick Municipalities, Rural Communities and Unincorporated Areas (2008). Available from: http://www2.gnb.ca/content/dam/gnb/ Departments/en/pdf/Publications/NBwindEnergy.pdf

28. Ontario Ministry of the Environment (MOE). Noise Guidelines for Wind Farms (2008). Available from: https://dr6j45jk9xcmk.cloudfront.net/documents/1683/ 164-noise-guidelines-for-wind-farms-en.pdf

29. Danish Ministry of the Environment. Bekendtgørelse Om Støj Fra Vindmøller (Statutory Order on Noise from Wind Turbines). Copenhagen: Danish Environmental Protection Agency (2011). Report No. Bekendtgørelse nr. 1284. Available from: http://eng.mst.dk/media/mst/66206/engelsk_ vindmoellebekendtgoerelse.pdf

30. Germany Bundesministerium der Justiz. Technische Anleitung Zum Schutz Gegen Lärm (TA Lärm) [Sixth General Administrative Provision on the Federal Pollution Control Act (Technical Instructions on Noise Abatement: Noise TA)]. Federal Law Gazette I (2000). Available from: http://www.umweltbundesamt.de/sites/ default/files/medien/pdfs/talaerm_en.pdf

31. Department of the Environment, Heritage and Local Government. Proposed Revisions to Wind Energy Development Guidelines 2006 Targeted Review in Relation to Noise, Proximity and Shadow Flicker. Dublin: Department of the Environment, Community and Local Government (2013). Available from: http://www.environ.ie/en/Publications/DevelopmentandHousing/ Planning/FileDownLoad, 34769, en.pdf

32. Barclay C. Wind Farms - Distance from Housing. London: House of Commons Library, UK Parliament (2012). Report No. SN/SC/5221. Available from: http://www.parliament.uk/briefing-papers/sn05221.pdf

33. Joshi S, Douglas JP, Hamberg A, Teshale S, Cain D, Early-Alberts J. Strategic Health Impact Assessment on Wind Energy Development in Oregon. Salem, OR: Public Health Division, Oregon Health Authority (2013). Available from: https://public.health.oregon.gov/HealthyEnvironments/TrackingAssessment/ HealthImpactAssessment/Documents/Wnd\%20Energy\%20HIA/Wind\% 20HIA Final.pdf

34. Geiger SS, Patch DL. New Hampshire Site Evaluation. Groton Wind (2010). Report No. Docket No. 2010. Available from: http://iberdrolarenewables.us.files. s3.amazonaws.com/pdf/groton-wind-SEC-application-032610.pdf

35. The State of Maine. Rule Chapters for the Department of Environmental Protection. The State of Maine (2014). Report No. Chapter 375. Available from: http://www.maine.gov/sos/cec/rules/06/chaps06.htm

36. Salt AN, Hullar TE. Responses of the ear to low frequency sounds, infrasound and wind turbines. Hear Res (2010) 268:12-21. doi:10.1016/j.heares.2010.06.007

37. Salt AN, Kaltenbach JA. Infrasound from wind turbines could affect humans. Bull Sci Technol Soc (2011) 31:296-302. doi:10.1177/0270467611412555
38. Møller H, Pedersen CS. Low-frequency noise from large wind turbines. J Acoust Soc Am (2011) 129:3727-44. doi:10.1121/1.3543957

39. Leventhall G. Infrasound from wind turbines-fact, fiction or deception. Can Acoust (2006) 34:29-36.

40. Persson Waye K, Öhrström E. Psycho-acoustic characters of relevance for annoyance of wind turbine noise. J Sound Vib (2002) 250:65-73. doi:10.1006/ jsvi.2001.3905

41. Boczar T, Malec T, Wotzka D. Studies on infrasound noise emitted by wind turbines of large power. Acta Phys Pol A (2012) 122:850-3.

42. O’Neal RD, Hellweg RD Jr, Lampeter RM. Low frequency noise and infrasound from wind turbines. Noise Control Eng J (2011) 59:135-57. doi:10.3397/ 1.3549200

43. Turnbull C, Turner J, Walsh D. Measurement and level of infrasound from wind farms and other sources. Acoust Aust (2012) 40:45-50.

44. Evans T, Cooper J, Lenchine V. Infrasound Levels near Wind Farms and in Other Environments. Adelaide, SA: South Australian EPA and Resonate Acoustics (2013). Available from: http://www.epa.sa.gov.au/xstd_files/Noise/ Report/infrasound.pdf

45. Evans T. MacArthur Wind Farm - Infrasound \& Low Frequency Noise. Adelaide, SA: Resonate Acoustics and AGL Energy Limited (2013). Report No. A12130. Available from: http://www.agl.com.au/ /media/AGL/About\%20AGL/ Documents/How\%20We\%20Source\%20Energy/Wind\%20Environment/ Macarthur\%20Wind\%20Farm/Assessment\%20and\%20Reports/2013/July/ 130724_Resonate\%20Acoustics\%20MWF\%20infrasound\%20report.pdf

46. Evans T, Cooper J, Lenchine V. Low Frequency Noise Near Windfarms and in Other Environments. Adelaide, SA: South Australian Environment Protection Authority, Resonate Acoustics (2013). Available from: http://www.epa.sa.gov.au/xstd files/Noise/Report/low_frequency.pdf

47. Bolin K, Bluhm G, Eriksson G, Nilsson ME. Infrasound and low frequency noise from wind turbines: exposure and health effects. Environ Res Lett (2011) 6:035103. doi:10.1088/1748-9326/6/3/035103

48. van den Berg F. Wind turbine noise: an overview of acoustical performance and effects on residents. Proceedings of Acoustics, Victor Harbor, SA (2013).

49. Sloven P. LFN and the A-weighting. J Low Freq Noise V A (2005) 24:157-62. doi:10.1260/026309205775374389

50. Health Canada. Wind Turbine Noise and Health. The Government of Canada (2014). Available from: http://www.hc-sc.gc.ca/ewh-semt/noise-bruit/ turbine-eoliennes/summary-resume-eng.php

51. Ambrose S, Rand R, Krogh C. Wind turbine acoustic investigation: infrasound and low-frequency noise - a case study. Bull Sci Technol Soc (2012) 32:128-41. doi:10.1177/0270467612455734

52. Richarz W, Richarz H, Gambino T. Correlating very low frequency sound pulse to audible wind turbine sound. Fourth International Meeting on Wind Turbine Noise. Rome (2011).

53. Tachibana H, Yano H, Fukushima A. Assessment of wind turbine noise in immission areas. Proc. 5th International Conference on Wind Turbine Noise. Denver, CO (2013).

54. Watanabe T, Møller H. Low frequency hearing thresholds in pressure field and in free field. J Low Freq Noise V A (1990) 9:106-15.

55. Evans T, Cooper J. Comparison of predicted and measured wind farm noise levels and implications for assessments of new wind farms. Acoust Aust (2012) 40:28-36.

56. Howe Gastmeier Chapnik Limited. Low Frequency Noise and Infrasound Associated with Wind Turbine Generator Systems: A Literature Review. Toronto, ON: Ontario Ministry of the Environment (2010). Report No. OSS078696. Available from: http://www.ontario.ca/environment-and-energy/lowfrequency-noise-and-infrasound-associated-wind-turbine-generator-systems

57. Roberts C. Ecoaccess guideline for the assessment of low frequency noise. Acoustics 2004. Gold Coast, QLD (2004).

58. Jakobsen J. Danish guidelines on environmental low frequency noise, infrasound and vibration. J Low Freq Noise V A (2001) 20:141-8. doi:10.1260/ 0263092011493091

59. Kamigawara K, Yue J, Saito T, Hirano T. Publication of "handbook to deal with low frequency noise (2004)". J Low Freq Noise V A (2006) 25:153-6. doi:10.1260/026309206778494292

60. Rand RW, Ambrose SE, Krogh CM. Occupational health and industrial wind turbines: a case study. Bull Sci Technol Soc (2011) 31:359-62. doi:10.1177/ 0270467611417849 
61. Walker BW, Hessler GF, Hessler DM, Rand R, Schomer PA. Cooperative Measurement Survery and Analysis of Low Frequency and Infrasound at the Shirley Wind Farm in Brown County, Wisconsin. Public Service Commission of Wysconsin (2012). Report No. 122412-1. Available from: http://psc.wi.gov/apps35/ERF_ view/viewdoc.aspx?docid $=178263$

62. Pierpont N. Wind Turbine Syndrome: A Report on a Natural Experiment. Santa Fe, NM: K-Selected Books (2009).

63. Dommes E, Bauknecht H, Scholz G, Rothemund Y, Hensel J, Klingebiel R. Auditory cortex stimulation by low-frequency tones - an fMRI study. Brain Res (2009) 1304:129-37. doi:10.1016/j.brainres.2009.09.089

64. Goerke V, Woodward M. Infrasonic observation of a severe weather system. Mon Weather Rev (1966) 94:395-8. doi:10.1175/1520-0493(1966)094<0395: IOOASW $>2.3 . \mathrm{CO} ; 2$

65. Goerke V, Young J, Cook R. Infrasonic observations of the May 16, 1963, volcanic explosion on the Island of Bali. J Geophys Res (1965) 70:6017-22. doi:10.1029/JZ070i024p06017

66. Wilson CR. Infrasonic pressure waves from the aurora: a shock wave model. Nature (1967) 216:131-3. doi:10.1038/216131a0

67. Bedard A Jr. Infrasound originating near mountainous regions in Colorado. J Appl Meteorol (1978) 17:1014-22. doi:10.1175/1520-0450(1978)017<1014: IONMRI $>2.0 . \mathrm{CO} ; 2$

68. Leventhall G, Pelmear P, Benton S. A Review of Published Research on Low Frequency Noise and its Effects. London: Department for Environment, Food and Rural Affairs (2003). Report No. EPG 1/2/50. Available from: http:// westminsterresearch.wmin.ac.uk/4141/1/Benton_2003.pdf

69. Yuan H, Long H, Liu J, Qu L, Chen J, Mou X. Effects of infrasound on hippocampus-dependent learning and memory in rats and some underlying mechanisms. Environ Toxicol Pharmacol (2009) 28:243-7. doi:10.1016/j.etap. 2009.04.011

70. Berglund B, Hassmen P, Job RS. Sources and effects of low-frequency noise. J Acoust Soc Am (1996) 99:2985-3002. doi:10.1121/1.414863

71. International Organization for Standardization (ISO). ISO 226:2003. AcousticsNormal Equal-Loudness Level Contours. 2nd ed. Geneva: ISO (2003).

72. Botha P. Ground vibration, infrasound and low frequency noise measurements from a modern wind turbine. Acta Acust United Acust (2013) 99:537-44. doi:10.3813/AAA.918633

73. Tachibana H, Yano H, Fukushima A, Sueoka S. Nationwide field measurements of wind turbine noise in Japan. Noise Control Eng J (2014) 62:90-101. doi:10.3397/1/376209

74. Mirowska M. Evaluations of low-frequency noise in dwelling. New polish recommendations. J Low Freq Noise V A (2001) 20:67-74. doi:10.1260/ 0263092011493163
75. Jakobsen J. Danish regulation of low frequency noise from wind turbines. J Low Freq Noise V A (2012) 31:239-46. doi:10.1260/0263-0923.31.4.239

76. Moorhouse A, Waddington D, Adams M. Proposed Criteria for the Assessment of Low Frequency Noise Disturbance. London: Department for Environment, Food and Rural Affairs (2005). Report No. NANR45. Available from: http://archive.defra.gov.uk/environment/quality/noise/research/lowfrequency/ documents/nanr45-criteria.pdf

77. Parnell J. Development of the draft NSW planning guidelines: wind farms. Acoust Aust (2012) 40:79-83.

78. Leventhall G. Low frequency noise and annoyance. Noise Health (2004) 6:59-72.

79. Broner $\mathrm{N}$, Leventhall $\mathrm{H}$. Low frequency noise annoyance assessment by low frequency noise rating (LFNR) curves. J Low Freq Noise V A (1983) 2:20-8.

80. Broner N. A simple criterion for low frequency noise emission assessment. Acoust Aust (2011) 39:7-14.

81. Leventhall G. Concerns about infrasound from wind turbines. Acoust Today (2013) 9:30-8. doi:10.3389/fpubh.2014.00220

82. Deignan B, Harvey E, Hoffman-Goetz L. Fright factors about wind turbines and health in Ontario newspapers before and after the Green Energy Act. Health Risk Soc (2013) 15:234-50. doi:10.1080/13698575.2013.776015

Conflict of Interest Statement: In terms of competing interests (financial and nonfinancial) the authors work for various consulting firms and have worked with wind power companies. The authors are actively working in the field of wind turbines as environmental health scientists and acoustical engineers. Although we make this disclosure, we wish to reiterate that as independent scientific professionals our views and research are not influenced by these contractual obligations.

Received: 02 December 2014; accepted: 06 February 2015; published online: 24 February 2015.

Citation: Berger RG, Ashtiani P, Ollson CA, Whitfield Aslund M, McCallum LC, Leventhall $G$ and Knopper LD (2015) Health-based audible noise guidelines account for infrasound and low-frequency noise produced by wind turbines. Front. Public Health 3:31. doi: 10.3389/fpubh.2015.00031

This article was submitted to Epidemiology, a section of the journal Frontiers in Public Health.

Copyright (c) 2015 Berger, Ashtiani, Ollson, Whitfield Aslund, McCallum, Leventhall and Knopper. This is an open-access article distributed under the terms of the Creative Commons Attribution License (CC BY). The use, distribution or reproduction in other forums is permitted, provided the original author(s) or licensor are credited and that the original publication in this journal is cited, in accordance with accepted academic practice. No use, distribution or reproduction is permitted which does not comply with these terms. 